\title{
A Basis Of Cultural Education: SAFEGUARDING INTANGIBLE HERITAGE Through A Web-BASEd Digital Photographic Collection
}

\author{
Chen Kim Lim ${ }^{1}$, Kian Lam Tan $^{2}$ and Nguarije Hambira ${ }^{3}$ \\ ${ }^{1,2,3}$ Department of Computing, Faculty of Arts, Computing and Creative \\ Industry, Universiti Pendidikan Sultan Idris (UPSI), 35900 Tanjung Malim, \\ Perak, Malaysia
}

\begin{abstract}
The $21^{\text {st }}$ century came with its own challenges as much as it brought various benefits through the advancement in technology. Cultural heritage is one such "casualty" of the developments in the $21^{\text {st }}$ century in that there has been a decline in appreciation and awareness of the importance of cultural heritage. Thus, the present study was necessitated with the primary aim of (i) preservation of the intangible cultural heritage of the people of Georgetown through the development of the E-George Town Digital Heritage (E-GDH) system (ii) develop an effective GUI for the E-DGH system in order to stimulate and captivate the attention of users with the aim of raising awareness as well to educate the masses on the importance of cultural heritage and (iii) to evaluate the effectiveness of the developed system in relation to its objective through the administration of questionnaires to target respondents. To this effect the study employed the use of the waterfall model to develop this E-GDH website. The study found that respondents (prior to using the E-GDH system) had no previous experience in terms of oral story telling from their parents. Overall, it was found that the GUI was pleasant and attractive for use by respondents and that they were able to learn easily as a result. Based on the fact that respondents where able to learn with ease due to an effective GUI, the study also revealed that the content they were learning from this website was actually easy for them to understand and that this website was indeed helpful in helping them to understand and appreciate cultural heritage. The meaning and conduct of the education sector in this era of advanced technology has shifted a lot over the years changing from teachers as the primary source of information to what is termed as "learner-centred" where they are given the leeway to learn, explore and make sense of the world around them and the findings from this study falls no short from this notion. The E-GDH website could be used by schools in subjects such as history where the teacher could use this website as reference point for a certain lesson outcome that deals with digital cultural heritage or intangible cultural heritage. Thus the study contributes immensely to the understanding of cultural heritage by raising awareness as well as stimulating the inters of the young generation to appreciate and learn more about their cultural heritage. The prominence of digitalising the intangible cultural heritage cannot be emphasised enough as recent study has shown decline in interests in these area so the development of the E-GDH is one such positive call to action in response to UNESCO's 2003 call for preservation of intangible cultural heritage and by extension, educating and raising awareness on the importance of cultural heritage.
\end{abstract}

\section{KEYWORDS}

Cultural Education, Digital Library, Digital Cultural Heritage, Digital Asset Management System, Digital Preservation 


\section{INTRODUCTION}

Culture education has to a lot with a type of learning that combines the beliefs, history, principles as well as the viewpoint of various people that comes from a variety of backgrounds that might be different not only culturally but also in terms of their way of life. Cultural heritage symbolizes the identity of the country while the awareness of this heritage among citizen illustrates the future of the country. The knowledge of the people about the history of a country's cultural heritage is very important to foster the love for their nation, especially in a multiracial nation such as Malaysia. According to Blake (2008) cultural heritage can be in the form of things you can physically touch or quantify (tangible cultural heritage) such as monuments or it can be in the form of things we cannot literally touch (intangible cultural heritage) such as oral storytelling, the traditional knowledge of a certain practice for instance surviving the scorching heat of the desert by using locally available materials such as plants and animal products. In the year 2003, the United Nations Educational, Scientific and Cultural Organization (UNESCO) acknowledged the importance of distinctly preserving the intangible cultural heritage the same way they do with tangible cultural heritage because intangible cultural heritage requires a different method of preservation. The preservation of intangible cultural heritage can be achieved in various ways and the one propagated by this study is that of digital preservation through the development of a web system. The issues that necessitated the present study were twofold: (i) there was a lack of interest among the younger generation to learn about their cultural heritage, (ii) there was also a lack of adequate online reading materials where people could read up on cultural heritage. Education in the $21^{\text {st }}$ century has changed from what was once the accepted norm of "teaching and learning". In this new era of technology, education has been "decentralised" in the sense that it has now shift to become learner centred compared to previously when it was teacher centred. To this effect, development of this web system as propagated for by the present study aims to preserve and educate the importance of local cultural heritage of the people of Georgetown by stimulating interest in this subject as well to educate the masses through the content provided forth on this website where various aspects of the intangible cultural heritage of the people of Georgetown would be taught and in so doing preserve these artefacts while raising awareness on these issues. Developing detailed systems that digitally manage the assets of a given museum at first glance might appear to be a difficult task but it does not necessarily have to. The main function of this system was to provide a solution to expose people to the wealth of cultural heritage in Malaysia. This research aims to capitalize on the fact that recent research has proven that there has been a drastic increase in the use of online content as a way to access information among internet users. The system provides a service whereby cultural heritage that is photographic in nature could be accessed digitally. Besides, the user would be able to use the search function to find the information they need.

Usually, users get their knowledge from oral stories taught by their grandparents as well as previous generation. Tebeau (2013) and Matusiak, Tyler, Newton and Polepeddi (2017) further expounded on this notion by highlighting that oral history plays a pivotal role of ensuring that the public is made aware and able to understand the origin as well as the way local communities socialise among each other. Thus this study was carried out with these primary objectives; (i) to preserve the cultural heritage of people at Georgetown through the development of the E-GDH system, (ii) ensure the effectiveness the E-GDH system through the development of an effective Graphic User Interface (GUI) that aims to attract and keep the young generation interests and (iii) evaluate the effectiveness of the E-DGH system through the deployment of questionnaire to target respondents. With the creation of the E-GDH, cultural heritage of the people of Georgetown, Penang can be preserved more effectively due to organization of content about cultural heritage and the user can also upload content to add more depth to the repository. Besides, the online discussions on E-GDH will keep users engaged substantially. The authors are of the strong believe that this study benefits the young generation by educating them on the importance of 
cultural heritage through the interactive content on the E-DGH website. Consequently, having these cultural artefacts digitalised helps by contributing to the UNESCO goals of intangible cultural heritage preservation.

\section{LITERATURE REVIEW}

According to Olson (2013) the discipline of archaeology is one that is disruptive in nature and the methods that are employed by most archaeologists with their task of recording and preserving such findings represent visuals through printing of two dimensional of objects that appears in 360 degrees' viewpoint. However, there is hope for this phenomena thanks to advancement in the technology of 3D that stands to bring about an overhaul to the discipline of archaeology. Advancement in 3D technology has resulted in development of software packages that makes it possible for the generation of more precise 3D models. One such software to be used in the discipline of archaeology was that of PhotoScan Pro that was used to record and digitalise heritage artefacts with greater accuracy, allowing for a new avenue through which data in this discipline could be disseminated.

Al-Barakati et al., (2014) indicated that storage of media information through the process of compressing and encryption is normally associated with digital asset management systems (DAMS). For the purposes of detecting temperament of these media files or for the management of copyrights related issues, it then becomes necessary for these compressed files to be watermarked. However, watermarking these media files is not as easy as it seems seeing that the process of compressing media files reduces the bits' value, also encrypting these files in addition to compression, leads to randomization of the bit stream. As a result, any attempt to watermarking these files leads to loss of quality. To this effect, it then becomes of paramount importance to ensure that the appropriate encryption is chosen that will provide counter measures to issues concerning loss of quality. Al-Barakati et al., (2014) suggested the use of these schemes to watermark the media files: Rational Dither Modulation (RDM) and Spread Spectrum (SS). The summary of other related articles to digital asset management is as follows (Table 1).

Table 1. Summary of Articles Related to Digital Asset Management (DAM).

\begin{tabular}{|c|c|c|c|}
\hline $\begin{array}{l}\text { Name Of Paper } \\
\text { (Authors, Years) }\end{array}$ & Brief Description & Strength(s) & Weakness(es) \\
\hline 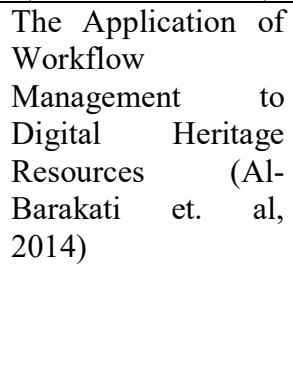 & $\begin{array}{l}\text { An experimental } \\
\text { Workflow management } \\
\text { System (WfMS) whose } \\
\text { aim were verifying the } \\
\text { validity of the } \\
\text { integration of } \\
\text { management workflow } \\
\text { in relation to Digital } \\
\text { Heritage Resources } \\
\text { (DHRs). }\end{array}$ & $\begin{array}{l}\text { The difficulties brought } \\
\text { about by implementing } \\
\text { DHR was easily overcome } \\
\text { through the deployment of } \\
\text { the WFMS. }\end{array}$ & $\begin{array}{l}\text { Implementing } \\
\text { DHR } \\
\text { "DISPLAYS" } \\
\text { framework was } \\
\text { only done as a } \\
\text { testing for the } \\
\text { WFMS. }\end{array}$ \\
\hline $\begin{array}{l}\text { Robustwatermarking } \\
\text { of Compressed and } \\
\text { Encrypted } \\
\text { JPEG2000 Images } \\
\text { (Subramanyam et al., } \\
\text { 2012) }\end{array}$ & $\begin{array}{l}\text { DAMS typically deals } \\
\text { with compression and } \\
\text { encryption of media } \\
\text { files. }\end{array}$ & $\begin{array}{l}\text { For the purposes of } \\
\text { tempering detection as } \\
\text { well as copyright issues, } \\
\text { the watermarking of } \\
\text { encrypted compressed } \\
\text { media files becomes even } \\
\text { more crucial. }\end{array}$ & $\begin{array}{l}\text { Watermarking } \\
\text { these encrypted } \\
\text { files results in the } \\
\text { loss of the quality } \\
\text { of the media file. }\end{array}$ \\
\hline $\begin{array}{l}\text { Digital Curation } \\
\text { Beyond the "Wild }\end{array}$ & $\begin{array}{l}\text { As an alternative to the } \\
\text { commonly used theory }\end{array}$ & $\begin{array}{l}\text { This alternative approach } \\
\text { is said to view }\end{array}$ & $\begin{array}{l}\text { The current } \\
\text { digitalization }\end{array}$ \\
\hline
\end{tabular}




\begin{tabular}{|c|c|c|c|}
\hline $\begin{array}{l}\text { Frontier': A } \\
\text { Pragmatic Approach } \\
\text { (Dallas, 2016) }\end{array}$ & $\begin{array}{l}\text { of digitalization, this } \\
\text { study proposed a more } \\
\text { logical approach as } \\
\text { compared to the } \\
\text { former. }\end{array}$ & $\begin{array}{l}\text { digitalization as a practice } \\
\text { where a range of actors } \\
\text { such as artists, local } \\
\text { communities and so on can } \\
\text { use the system beyond the } \\
\text { normal or rather expected } \\
\text { life cycle. }\end{array}$ & $\begin{array}{l}\text { strategy is limited } \\
\text { in that the funding } \\
\text { of applications, } \\
\text { marketing, } \\
\text { persuasiveness in } \\
\text { attracting users as } \\
\text { well as setting up } \\
\text { of intellectual } \\
\text { properties. }\end{array}$ \\
\hline $\begin{array}{l}\text { Streaming The } \\
\text { Archives: } \\
\text { Repurposing } \\
\text { Systems to Advance } \\
\text { a Small Media } \\
\text { Digitization and } \\
\text { Dissemination } \\
\text { Program (Anderson, } \\
2015)\end{array}$ & $\begin{array}{l}\text { The present study gives } \\
\text { account of the journey } \\
\text { taken by an archivist in } \\
\text { their first year of using } \\
\text { the system. }\end{array}$ & $\begin{array}{l}\text { It was reported that the } \\
\text { system was able to provide } \\
\text { for good storage during the } \\
\text { time of use. }\end{array}$ & $\begin{array}{l}\text { Regardless of its } \\
\text { inability to } \\
\text { provide } \\
\text { responsive } \\
\text { metadata, } \\
\text { YouTube is seen } \\
\text { to continue being } \\
\text { the source of } \\
\text { information } \\
\text { distribution across } \\
\text { various platforms. }\end{array}$ \\
\hline $\begin{array}{l}\text { The Tel Akko Total } \\
\text { Archaeology Project } \\
\text { (Akko, Israel): } \\
\text { Assessing the } \\
\text { Suitability of Multi- } \\
\text { scale 3D Field } \\
\text { Recording in } \\
\text { Archaeology } \\
\text { et al., 2013) }\end{array}$ & $\begin{array}{l}\text { Due to successful } \\
\text { testing, the use of } \\
\text { PhotoScan Pro has } \\
\text { been adopted for use in } \\
\text { the Akko Project given } \\
\text { its commercial success } \\
\text { since launching. }\end{array}$ & $\begin{array}{l}\text { The use of PhotoScan Pro } \\
\text { for archaeological } \\
\text { purposes has been proven } \\
\text { to be a success due to its } \\
\text { ability to increase the } \\
\text { accuracy in terms of the } \\
\text { way it records and } \\
\text { digitalises heritage } \\
\text { artefacts. In so doing, it } \\
\text { provides for an alternative } \\
\text { way that allows for the } \\
\text { distribution of data in the } \\
\text { area of archelogy. }\end{array}$ & $\begin{array}{l}\text { The use of this } \\
\text { software } \\
\text { sometimes leads } \\
\text { to loss of quality } \\
\text { in the media files. }\end{array}$ \\
\hline $\begin{array}{l}\text { Camera-Based } \\
\text { Whiteboard Reading } \\
\text { For Understanding } \\
\text { Mind Maps (Vajda } \\
\text { et al., 2015) }\end{array}$ & $\begin{array}{l}\text { The study was aimed at } \\
\text { producing digitally } \\
\text { illustrated mind maps } \\
\text { which would allow for } \\
\text { digitally managing } \\
\text { assets through storage } \\
\text { and retrieval of such } \\
\text { records. }\end{array}$ & $\begin{array}{l}\text { This system was founded } \\
\text { on the idea of imaging } \\
\text { through the use of cameras } \\
\text { thereafter followed by } \\
\text { extracting the whiteboard } \\
\text { segments for any written } \\
\text { texts as portrayed in the } \\
\text { mind map. }\end{array}$ & $\begin{array}{l}\text { The developed } \\
\text { system was } \\
\text { evaluated using } \\
\text { only evaluation } \\
\text { that was } \\
\text { experimental and } \\
\text { unconfined. }\end{array}$ \\
\hline $\begin{array}{lr}\text { Descriptive } & \\
\text { Metadata: } & \text { An } \\
\text { Analysis of } & \text { British } \\
\text { Path Newsreel } \\
\text { Collections from } \\
\text { World War Two } \\
\text { (Addica, 2017) }\end{array}$ & $\begin{array}{l}\text { A digitalized system } \\
\text { that allowed for the } \\
\text { archiving and search } \\
\text { functions. }\end{array}$ & $\begin{array}{l}\text { The use of simple search } \\
\text { phrases as well as a clearer } \\
\text { scheme could have made } \\
\text { the system user friendly by } \\
\text { providing ease of access } \\
\text { and use. }\end{array}$ & $\begin{array}{l}\text { The conversion of } \\
\text { the negative films } \\
\text { into digital form } \\
\text { lacked } \\
\text { information that } \\
\text { was complete and }\end{array}$ \\
\hline
\end{tabular}




\begin{tabular}{|c|c|c|c|}
\hline & & & detailed. \\
\hline \begin{tabular}{lr}
\multicolumn{2}{l}{ Systems Information } \\
Modelling: Enabling \\
Digital r & Asset \\
Management & (Love \\
et al., 2016) &
\end{tabular} & $\begin{array}{l}\text { The use of Computer- } \\
\text { Aided-Design (CAD) } \\
\text { provides managers } \\
\text { with "on the go" } \\
\text { documentation. }\end{array}$ & $\begin{array}{l}\text { The use of CAD is not } \\
\text { suitable for use across the } \\
\text { board and this is evident } \\
\text { with electrical engineering } \\
\text { systems that involves a } \\
\text { great deal of complexity } \\
\text { due to its various } \\
\text { components that } \\
\text { incorporates the use of } \\
\text { geometrical concepts that } \\
\text { are not supported by CAD } \\
\text { at the moment. }\end{array}$ & $\begin{array}{l}\text { The optimization } \\
\text { of performances } \\
\text { when it comes to } \\
\text { asset systems has } \\
\text { been } \\
\text { compromised due } \\
\text { to the inability of } \\
\text { having the } \\
\text { required } \\
\text { information at the } \\
\text { required time. }\end{array}$ \\
\hline $\begin{array}{l}\text { Advocating for } \\
\text { Sustainability: } \\
\text { Scaling-Down } \\
\text { Library Digital } \\
\text { Infrastructure } \\
\text { (Montoya, 2016) }\end{array}$ & $\begin{array}{l}\text { The present study } \\
\text { illustrated why those in } \\
\text { charge of the library } \\
\text { administration were } \\
\text { ought to campaign } \\
\text { systematically } \\
\text { producing platforms } \\
\text { that are scaled down in } \\
\text { nature. }\end{array}$ & $\begin{array}{l}\text { Environments keep } \\
\text { changing technically and } \\
\text { therefore it creates a need } \\
\text { for libraries to adopt } \\
\text { platform cultures that are } \\
\text { more sustainable. }\end{array}$ & $\begin{array}{l}\text { The nature of } \\
\text { Content } \\
\text { Management } \\
\text { Systems (CMSs) } \\
\text { is one that is } \\
\text { complicated and } \\
\text { forever evolving } \\
\text { and this creates a } \\
\text { scenario where } \\
\text { infrastructures are } \\
\text { not able to } \\
\text { achieve the goals } \\
\text { or rather the } \\
\text { needs of small } \\
\text { projects. }\end{array}$ \\
\hline $\begin{array}{l}\text { Digital Asset } \\
\text { Management: } \\
\text { Where to Start } \\
\text { (McGovern, 2013) }\end{array}$ & $\begin{array}{l}\text { The study proposed a } \\
\text { framework that } \\
\text { institutions could use } \\
\text { to digitally manage } \\
\text { their assets through } \\
\text { planning which } \\
\text { includes standards } \\
\text { setting tasking as well } \\
\text { as decision making. }\end{array}$ & $\begin{array}{l}\text { The creation of a more } \\
\text { complete document } \\
\text { planner stands to provide } \\
\text { institutions a cornerstone } \\
\text { of all their digital } \\
\text { programs as well as } \\
\text { providing for a RFP in the } \\
\text { future for a possible } \\
\text { management system for } \\
\text { their assets. }\end{array}$ & $\begin{array}{l}\text { There is a need } \\
\text { for DAM } \\
\text { strategies that } \\
\text { aims to tackle the } \\
\text { distribution of } \\
\text { digitalised assets } \\
\text { that could be used } \\
\text { in creating and } \\
\text { maintenance of } \\
\text { websites that are } \\
\text { engaging in } \\
\text { nature. }\end{array}$ \\
\hline
\end{tabular}




\section{Digital LiBRARIES}

Ross (2012) highlighted the importance of ensuring that preservation of bit streams and the way it is represented by stating that within the context of digitalized collections maintenance of such collections should always be sort after. However, there are some challenges towards implementation of their goals of digitalizing their artefacts faced by many of the small-to-medium sized institutions that are built with the primary aim of cultural heritage. These challenges include issues such as reduced man power, reduced monetary support and infrastructures that technically are not compatible with latest technology. All these challenges reduce the institutions' capability of preserving their content digitally (Schumacher et al., 2014). There are a few case studies that are used in this research such as Victoria \& Albert (V\&A) Digital Museum, British Digital Library and Johnson Museum of Art (Figure 1). Boasting an amazing collection of well over two million artefacts that spreads over a period up to 5000 years, the $\mathrm{V}$ and $\mathrm{A}$ is considered the front runner in terms of museums concerned with artistry and designs. This museum is home to a wealth of study materials for disciplines ranging from architecture, textile, book art to furniture and jewellery.

Another such library is that of the United Kingdom, it is the national library of the country and among the world's greatest of all times. With a collection up to 150 million artefacts that covers a wide range of well over 400 languages on top of up to 3 million pieces being added all year round. Their users can easily retrieve these collections, thanks to a library staff policy that allows for up to 30 minutes fully dedicated to tenting to users' enquiries as far as their collection goes (Schumacher et al., 2014).

Another museum that is equally committed to providing service to an audience that is diverse, is none other than the Herbert F. Johnson Museum of Arts. It opened its doors in the 1973 and it continued offering their services free of charge up until this very day. This museum does a great job when it comes to preserving its cultural artefacts for the present and future generations. The museum accomplishes this tasks through by connecting their audience with past arts and guides them in exploring latest developments in current arts.

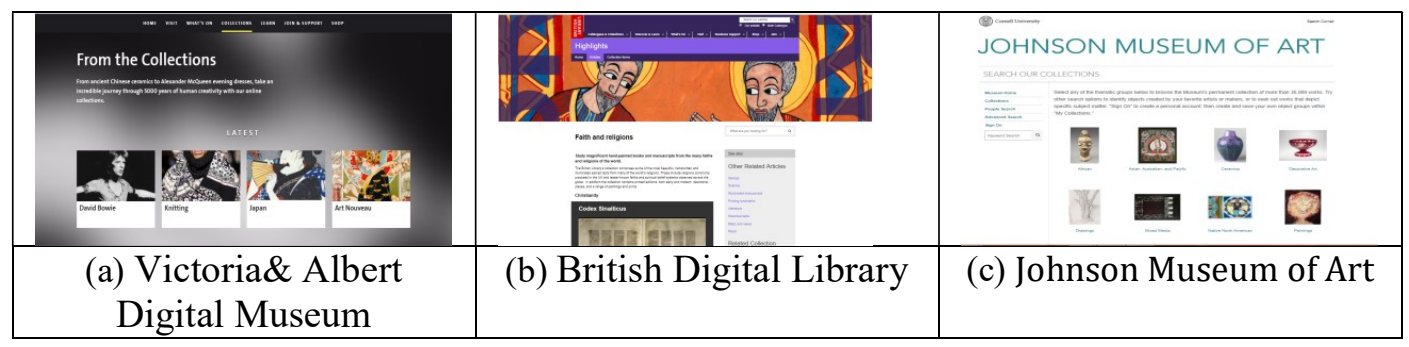

Figure 1. Various Digital Museum (a) Victoria\& Albert Digital Museum, (b) British Digital Library, (c) Johnson Museum of Art

\section{Methodology}

The present study adopted the use of the four phase waterfall model as the methodology for this research (Figure 2). The first phase was the requirement analysis and it entailed the collection of information through a survey questionnaire as well as interview sessions. Heritage photos characterising the people of Georgetown, Penang on 80-an were collected. These were than categorized into themes like race, type of attire, daily work and the facial appearance of people of Georgetown. The importance of the requirement phase could not be emphasised enough as the 
overall functions and system limitations begins with this phase in terms of what the user expects from the system and what the completed system offers to the users.

In the design phase, the activities carried out were website design sketches, database designs, input and output designs, and website interface sketches that were used throughout the implementation of this website. The primary software used in developing this website was the Brackets, a free and open source code editor designed and developed by Adobe Systems. This platform was chosen due to its "live" editing abilities, that is to say with Brackets all changes made to the source code is directly reflected in the browser widow, in so doing it reduces the need for a developer to constantly keep refreshing the page to see the latest changes which saves a developers' time a great deal. Website design is said to be of utmost importance when it comes to translating business requirements into system designs that goes on to meet the needs of its intended users. To this effect the researchers saw to it that the design process was carefully executed in order to ensure that the finished website would be easily usable in providing complete and accurate information about the cultural heritage of the people of Georgetown. The design phase was divided into two sections; the first was more concerned with the database design whereas the second phase was primarily concerned with the graphic user interface (GUI) design. As for the development phase, the database was developed through the use of PhP MyAdmin and made use of the SQL language. This platform was chosen due to its widely available resources and tutorials, also it was chosen due to the fact that is freely available and thanks to a large community of developers and contributors it is considered relatively more secure. The E-GDH system required a database so as to keep, retrieve and manipulate cultural heritage of the people of Georgetown in real time. To connect the front-end (website GUI) to the back-end (database) the use of the PhP server based scripting language was adopted for use in this study.

The fourth and final phase included the evaluation of various components of the system such as the GUI evaluation by both the administrator as well as normal user respondents. Both of these evaluations were executed in terms of a questionnaire survey distributed to target respondents. The user evaluation was carried out on 20 randomly selected respondents from the Faculty of Human Sciences, Department of History who successfully completed and submitted the questionnaire survey.

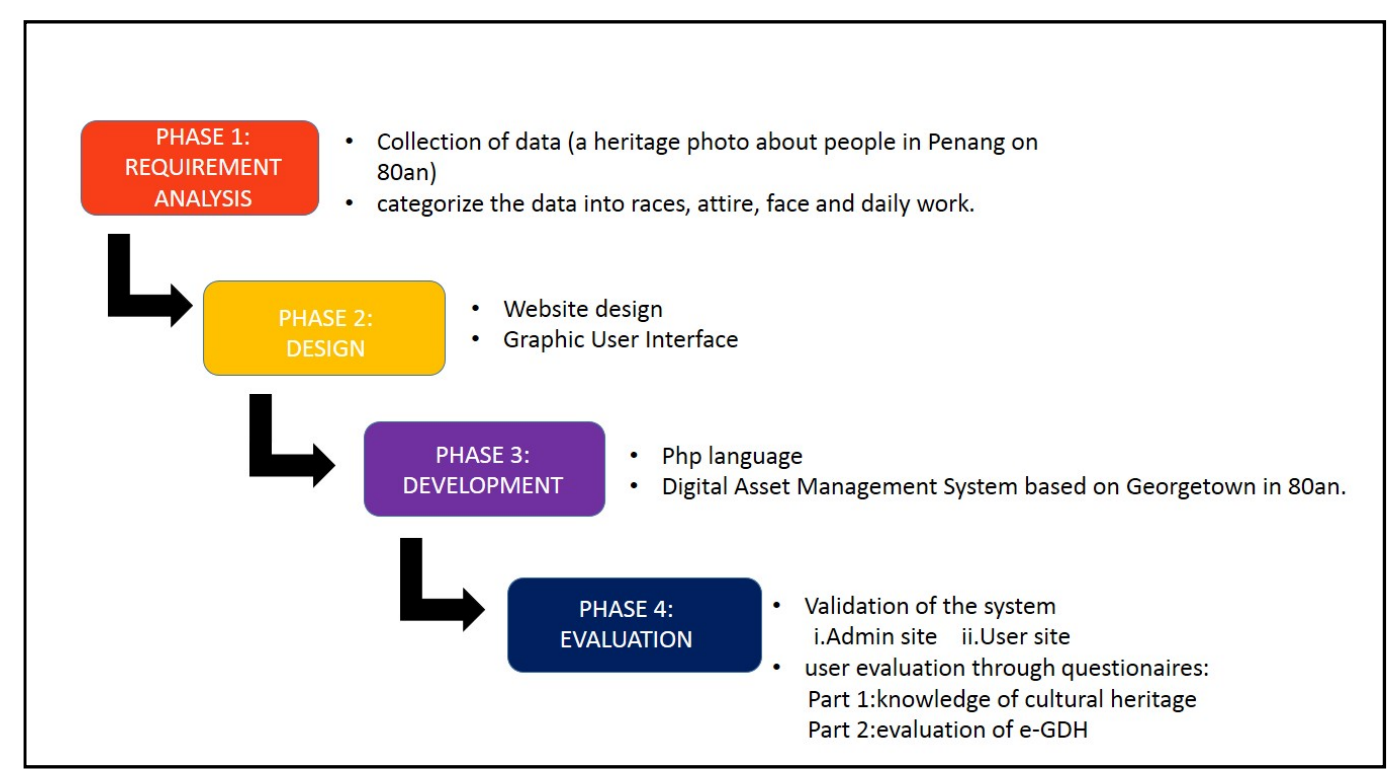

Figure 2. Research Methodology 


\section{DEVELOPMENT}

A web-based digital asset management system based on Georgetown in 80-an was developed by using the PHP language (Figure 3). The index page contained the form element that allowed the administrator or normal user login options into the system (Figure 3, a). The system made use of the ' $\mathrm{H}$ ' symbol to represent heritage. The researchers of the present study adopted the name electronic Georgetown digital heritage (E-GDH) as the official name for this system. There two main users for this system can either press the 'login as admin' if they are admin users which will redirect them to the admin page login session while 'login as user' button will direct to user login page. For the user logged in as admin, the main page will display the various functions they could perform (Figure 3b). When the admin clicks the button 'upload picture', the system will display an interface as shown in Figure 3(c). The page will request the admin to insert picture name, the description of the picture, select the race and type of attire, daily work as well as face. Next, the admin will have to click the button 'choose file' to select the image from their computers. The system will accept all type of image file format like JPEG, GIF, BMP, TIFF and PNG the admin could then press the submit button to finish this process. If the image was successfully inserted, the system message will display a message "Congratulations, the image was successfully uploaded" meanwhile if the process is not success the system will display a fail message. Cultural heritage photos can be viewed according to race such as British, Chinese, Indian and Malay (Figure $3 \mathrm{~d}-\mathrm{g}$ ). The system will display the title of the picture as well as its description. On the admin panel, each photo provides a button for update and delete the record. The searching function can help the user to get information that they want in a quick time (Figure 2i). The system will display a selection of the race and type of attire, daily work and face.

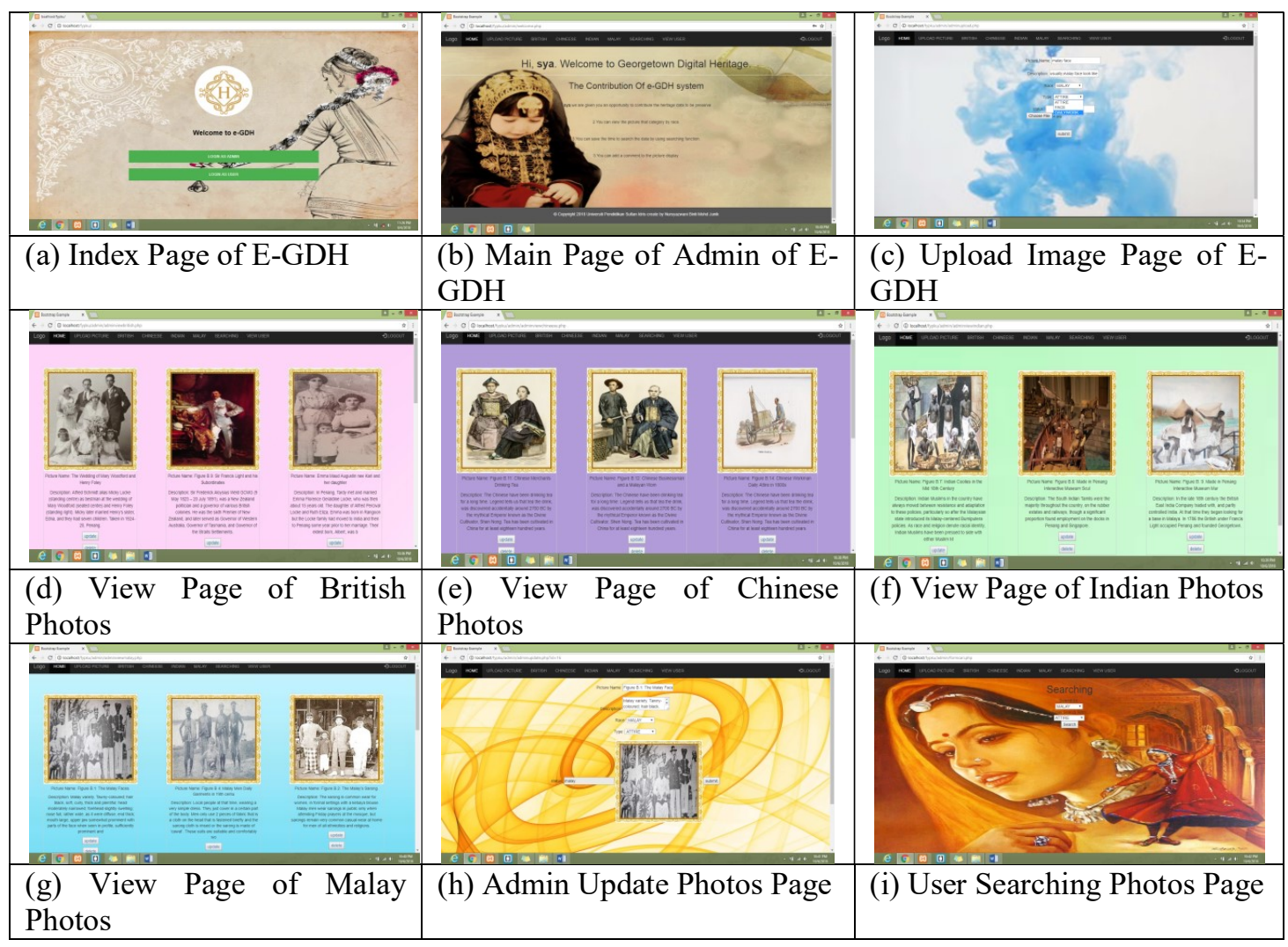

Figure 3. A Walkthrough of a Web-based Digital Asset Management System (E-GDH) 


\section{EVALUATION}

The purpose of this evaluation was to investigate if the objectives as outline in the first section of this paper has been achieved or not through the distribution of questionnaires to the target respondents. This study made use of students from Sultan Idris Education University as their primary target respondents in evaluating the E-GDH system. Twenty (20) respondents from the history education (AT32) course were able to complete and submit the evaluation form. Range of respondent's age ranged from 20 years old and below, 21-23 years old, 24-26 years old and 27 years old and above. The respondents were first exposed to the E-GDH system and after spending sometime interacting with the website they were asked to complete the questionnaire by providing evaluation on the usability of the system.

The questionnaire was made up of three sections, whereby the first section asked for demographic information of the respondents. The second section, was drawn up to test for the target respondents' basic knowledge about cultural heritage whereas the third section looked at evaluation of the E-GDH system. Upon completion of the data collection process, the data analysis was done through the use of IBM SPSS statistical software version 21. Statistical tests executed in SPSS were the mean and standard deviation tests. These test were tested on the Likert scale questionnaire items as indicated in the questionnaire survey. However, using descriptive analysis the tendency level was interpreted into several stages which were low (mean score: 1.002.40), average (mean score: 2.41-3.80) and high (mean score: 3.81-5.00).

Based on the section of basic cultural heritage knowledge, majority of the students (20) answered 'yes' that indeed they had a basic understanding of the cultural heritage concept (Figure 4). Majority (15) of the target respondents indicated that they did not have experience with oral story telling by their parents or elders compared to a minortiy (5) of the respondents who had experienced oral story telling from their elders. A slight majority (11) of the respondents had no knowledge of the importance of cultural heritage for the younger generation and the same holds true when it comes to the question item that asked if they knew the causes for low interest in cultural heritage by the younger generation, most respondents (15) indicated that they did not know what the factors were.

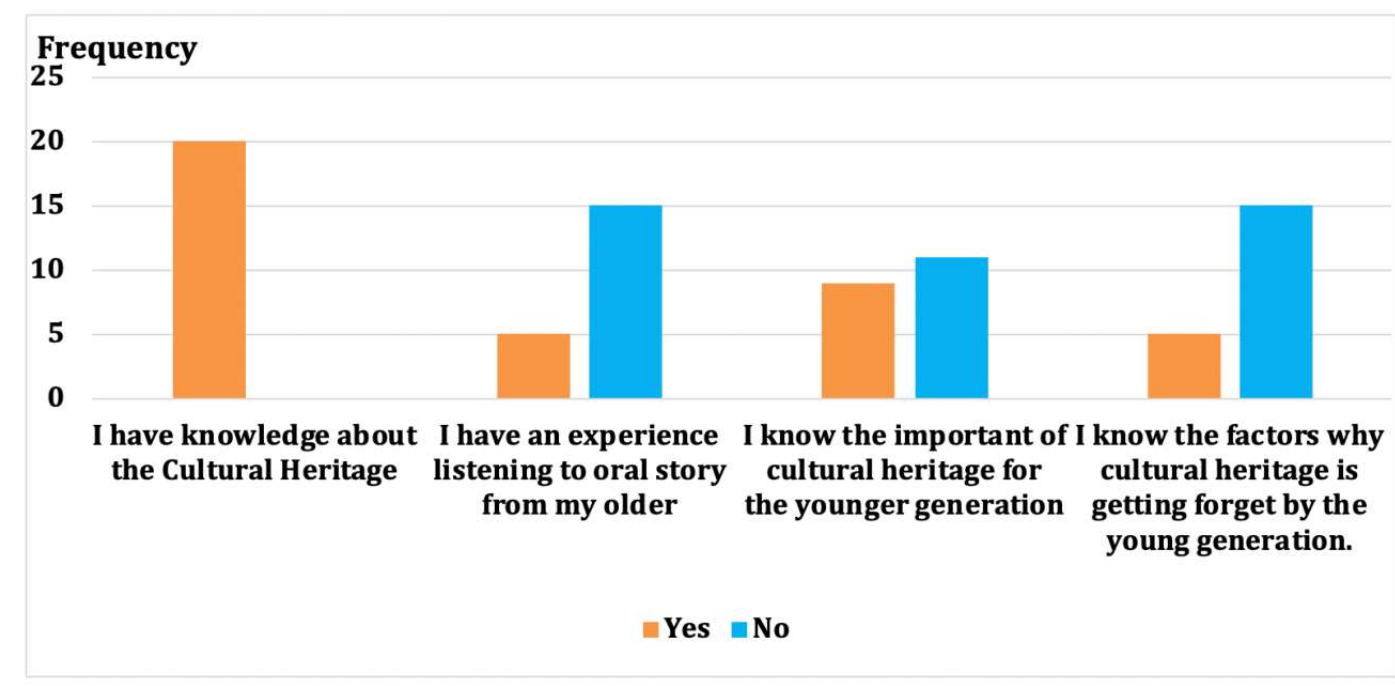

Figure 4. Evaluation for the Second Section Questionnaire 
The third section was divided into three subsections that looked into the evaluation of the GUI (Figure 5), the content provided forth by the E-GDH system (Figure 6) and the third subsection looked at testing for effectiveness of the E-GDH system (Figure 7). This question items were meant to test for ease of use and overall appearance of the system from the target respondents.

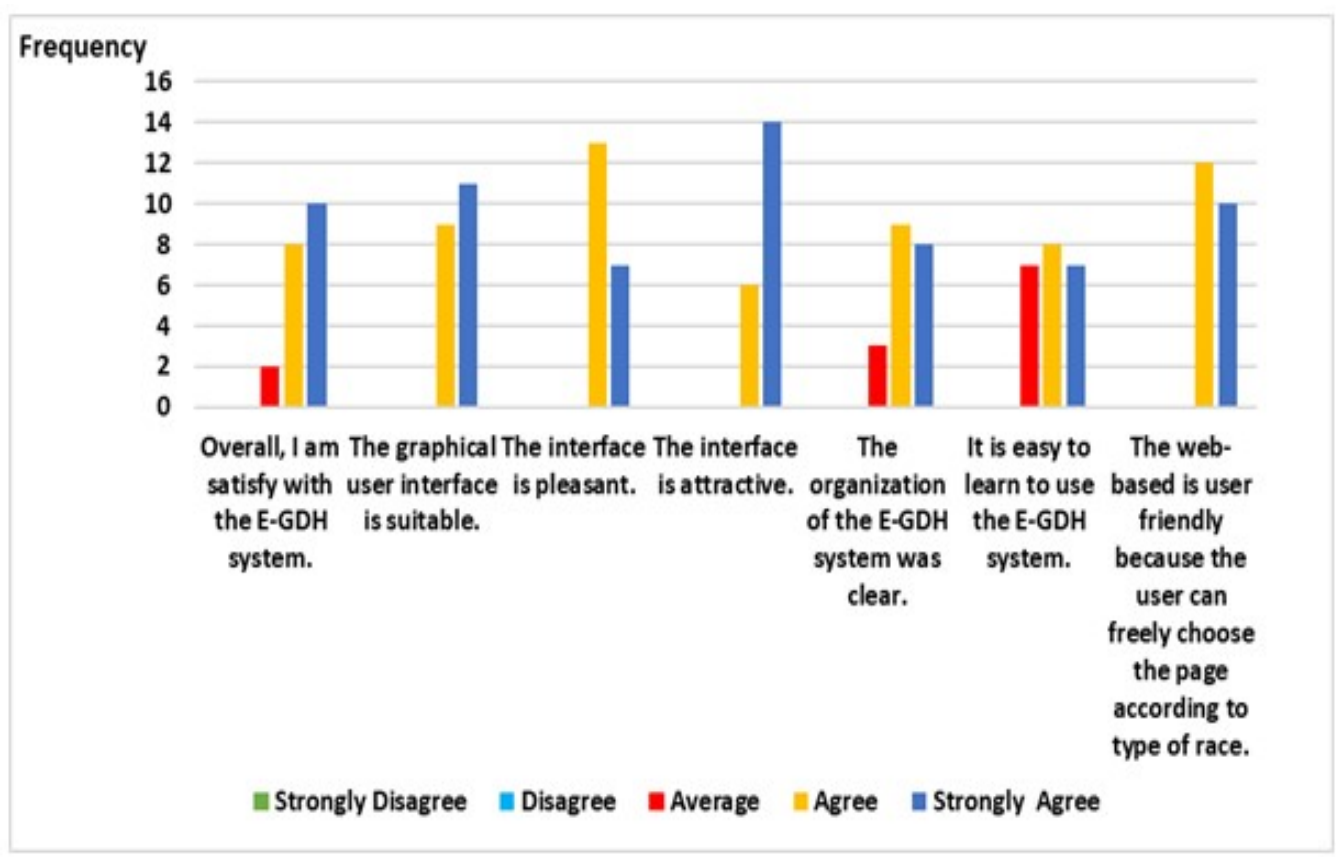

Figure 5. Evaluation of the Interface of the E-GDH System

From the question item that asked the respondents overall view on system (Figure 5), majority of the respondents either strongly agreed (10) or agreed (8) with the question item as compared to only two respondents who were recorded as average or neutral on the question item. For the question item that asked if the GUI was suitable for this purpose, majority of the all respondents either strongly agreed (11) or agreed (9) that the GUI was indeed suitable. The same holds true for the question item that asked if the respondents found the interface pleasant as most respondents either strongly agreed (7) or agreed (13) with the question item. The interface of the system was shown to be attractive as most respondents either strongly agreed (14) or agreed (6) with the corresponding question item. Similarly, organisation of the E-GDH system was said to be clear as shown by the responses (strongly agreed, 8; agreed 9). Majority of the target respondents ( 7 strongly agreed, 8 agreed) also indicated that it was easy to learn when it comes to using this system.

As for the second subsection that seek to evaluate the content provided forth by the E-GDH system, it was reported (Figure 6) that the content provided on this website was suitable for use by people of all ages as majority of the target respondents either strongly agreed (5) or agreed (8). The question item that asked if it was easy to understand the content on the E-GDH website showed that the content was easily understood as majority of the respondents either strongly agreed (8) or agreed (7) with the question item. The same holds true for the question item that asked if the E-GDH was a good source of knowledge acquisition, majority of the responses either strongly agreed (12) or agreed (8). Additionally, it was shown by the majority of responses (14 strongly agreed, 6 agreed) that the type of data on the site was suitable with the E-GDH system. The majority of target respondents (13 strongly agreed, 7 agreed) that the introduction of this system was helpful in helping the understanding of the cultural heritage. 


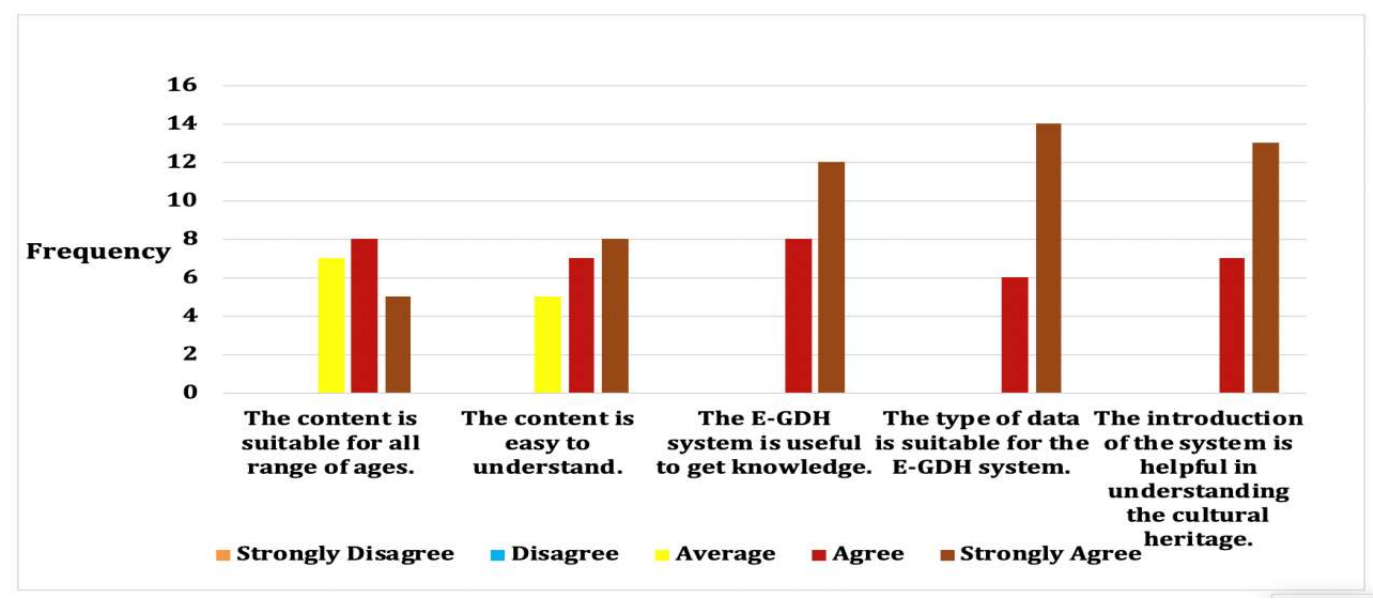

Figure 6. Evaluation of the Content on the E-GDH System

The third and final subsection of the three subsections under the evaluation category was concerned with evaluation of the effectiveness of the E-GDH system (Figure 7). As for the question item that asked if after using the system, respondents understood more about cultural heritage or not, majority of the target respondents either strongly agreed (6) or agreed (9) with the question item while 5 respondents were neutral or average on this question item. The same trend in responses was observed with the question item that asked if the E-GDH system was able to give knowledge about cultural heritage or not, majority of respondents to this effect either strongly agreed (8) or agreed (9) with the question item. Majority of the respondents were also able to differentiate facial differences between the various races as they either strongly agreed (13) or agreed (7) with the question item. Similarly, they were also able to distinguish between these races in terms of the attire they wore as majority of them either strongly agreed (7) or agreed (9) with the question item. As for the question that asked if respondents could differentiate between these races in terms of the type of work they did on a daily basis, majority of respondents either strongly agreed (11) or agreed (12). The last question item under this subtopic asked if respondents found the faces in synchronization with the type of attire, work done by each race or not and majority of responses to this effect either strongly agreed (11) or agreed (9) with the question item.

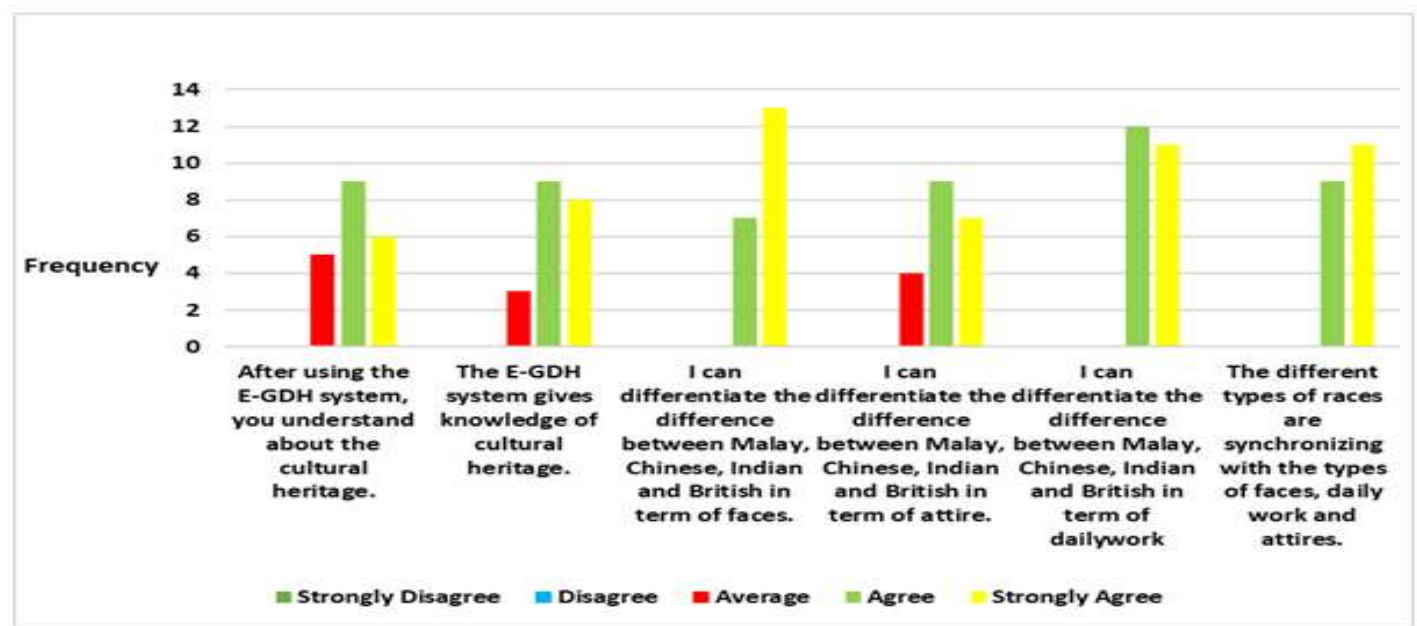

Figure 7. Evaluation of the Effectiveness of E-GDH System 
In summation of the evaluation herein, it can be seen from the responses that overall respondents had general knowledge about cultural heritage, however, majority of the respondents (15) had no prior experience in listening to oral stories taught by their parents. From the overall question items that asked about the GUI of the E-GDH website the majority of responses in all these subsection items revealed that the graphic user interface (GUI) was satisfactory and that they had a pleasant time using the website as a result. It was also mentioned that due to overall good GUI design, it was then easy for them to learn with ease on how to use this system. As for the question items that asked respondents about the content used on the website majority of the respondents from all the sub question items indicated that they found the content suitable for use across all age groups and that the content was easily understandable. Most importantly the evaluation found that the E-GDH website was indeed a useful place for them to get knowledge about cultural heritage. The question items that asked if the E-GDH website was effective in educating the masses, responses indicated that overall the website was effective in educating them about cultural heritage as they were able to distinguish between various attires, type of work done by various races as depicted in the website.

\section{CONCLUSIONS AND FUtURE WORK}

In conclusion, digital archiving or digital documentary initiative is a long-term planning as one great alternative for cultural education. The development of the E-GDH system has enabled for the preservation of the cultural heritage in Georgetown. As the results from this study have indicated, the E-GDH website was designed to optimise learning and the content on the website was proved to be easy to learn and suitable. Results from this study have also shown that the respondents were able to differentiate between the different races based on their cultural heritage as portrayed in the website. This goes on to indicate that learning has taken place in a smooth and efficient manner that was both beneficial to the users of this online system as well as to the overall cultural heritage in Georgetown. As with any other academic studies, there were however limitations as far as the system functionality or target population are concerned. Due to the limitation in acquiring extensive data about the cultural heritage across Malaysia, the E-GDH system thus only placed focus on the people of Georgetown, Penang and the other limitation was the time required to analyse and select the most suitable data for display on the website. It is suggested that for future studies, development of E-GDH system or similar systems incorporate the availability of such systems on mobile platform seeing that recent research has shown that majority of web access is usually done through the use of mobile phones and mobile devices.

\section{ACKNOWLEDGEMENTS}

The authors would like to thank Nursyazwani binti Mohd Junik for developing the website.

\section{REFERENCES}

[1] Addica, K. (2017). Descriptive Metadata: An Analysis of British Pathé Newsreel Collections from World War Two. Libri.67(2). pp. 141-148.

[2] Al-Barakati, A., White, M., \& Patoli, Z. (2014). The Application of Workflow Management to Digital Heritage Resources. International Journal of Information Management.34(5). pp. 660-671.

[3] Anderson, T. (2015). Streaming the Archives: Repurposing Systems to Advance a Small Media Digitization and Dissemination Program. Journal of Electronic Resources Librarianship.27(4). pp. 221-231.

[4] Blake, J. (2008). UNESCO's 2003 Convention on Intangible Cultural Heritage: The implications of community involvement in 'safeguarding'. In Intangible heritage (pp. 59-87). Routledge. 
[5] Dallas, C. (2016). Digital Curation Beyond The "Wild Frontier": A Pragmatic Approach. Archival Science.16(4). pp.421-457.

[6] Love, P. E., Zhou, J., Matthews, J., \& Luo, H. (2016). Systems Information Modelling: Enabling Digital Asset Management. Advances in Engineering Software. 102.pp.155-165.

[7] Matusiak, K., Tyler, A., Newton, C., \& Polepeddi. P. (2017). Finding Access and Digital Preservation Solutions for A Digitized Oral History Project. Digital Library Perspectives. 33(2). pp. 88-99.

[8] McGovern, M. (2013). Digital Asset Management: Where to Start. Curator: The Museum Journal. 56(2). pp.237-254.

[9] Montoya, R. D. (2016). Advocating for Sustainability: Scaling-Down Library Digital Infrastructure. Journal of Library Administration.56(5). pp.603-620.

[10] Olson, B., Placchetti, R., Quartermaine, J., \& Killebrew, A. (2013). The Tel Akko Total Archaeology Project (Akko, Israel): Assessing The Suitability of Multi-Scale 3d Field Recording in Archaeology. Journal of Field Archaeology. 38(3). pp. 244-262.

[11] Ross, S. (2012). Digital preservation, archival science and methodological foundations for digital libraries. New Review of Information Networking, 17(1), 43-68.

[12] Schumacher, J., Thomas, L. M., VandeCreek, D., Erdman, S., Hancks, J., Haykal, A., ... \& Spalenka, D. (2014). From theory to action: "good enough" Digital preservation solutions for under-resourced cultural heritage institutions. The Digital POWRR (Preserving Digital Objects with Restricted Resources) White Paper. Retrieved from: http://commons.lib.niu.edu/handle/10843/13610

[13] Subramanyam, A. V., Emmanuel, S., \& Kankanhalli, M. S. (2012). Robust Watermarking of Compressed and Encrypted JPEG2000 Images. IEEE Transactions On Multimedia. 14(3). pp. 703716.

[14] Tebeau, M. (2013). Listening to The City: Oral History and Place in The Digital Era. Oral History Review.40 (1). pp 25-35.

[15] Vajda, S., Plötz, T., \& Fink, G. A. (2015). Camera-Based Whiteboard Reading for Understanding Mind Maps. International Journal of Pattern Recognition and Artificial Intelligence.29(03). pp. 1553003. 


\section{Authors}

C. K. LIM has earned her doctorate from the School of Computer Sciences at Universiti Sains Malaysia (USM) in 2014 with the attachment in Université Joseph Fourier (UJF), France under the MFUC scholarship (2012-2014) at INRIA Grenoble. Currently, she is a senior lecturer in the Computing Department, FSKIK, Sultan Idris Educational University. She previously served as a deputy director II for assessment and instrumentation at UPSI Educational Research Lab (UERL). She specializes in computer

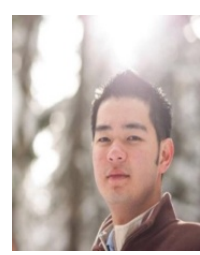
graphics, digital heritage, visual informatics, crowd simulation and rendering. She has published various proceedings and journal articles.

K. L. Tan has worked as a Research Scientist at Universite Grenoble Alpes focusing in the area of lifelogging and tourism by using the technology of deep learning and social network in 2016. He was partially sponsored by MFUC to pursue a Joint-Ph.D. program at Universite Grenoble Alpes (UGA) and Universiti Sains Malaysia (USM) and graduated in 2014. In 2008, he worked for Intel as a software engineer for almost 2 years and successfully deployed several automation software solutions in the United States, India, and China. His research interests spams across Information Retrieval

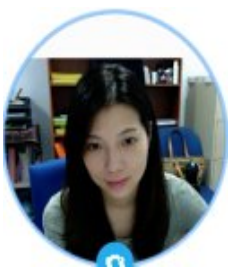
(IR), Big Data Analysis (BDA) and mobile game. Tan is presently employed as a senior lecturer at Sultan Idris Education University. He has published more than 35 proceedings and journal articles. He also acts as an advisor in the National Child Data Centre (NCDC).

N. Hambira is an aspiring young researcher with an immense interest in the area of information technology and its integration in the education sector. He obtained his honours degree from Sultan Idris Education University in 2017 and has gone on to publish over 5 conference proceedings and journal papers. He is presently pursuing his master's degree in education with specialisation in information technology. He has extensive experience in research and publication gained while working as a research assistant during his undergraduate as well as postgraduate studies at Sultan Idris

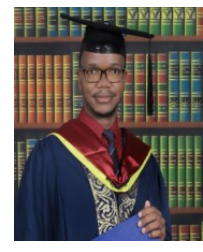
Education University. 